\title{
Progressivity Punggawa-Sawi in Sustaining Flying Fish Resources on Culture Patorani Takalar District South Sulawesi Indonesia
}

Hasriyanti

State University of Makassar

Erman Syarif

State University of Makassar (Correspondent)

Ach. Fatchan

State University of Malang

Sumarmi

State University of Malang

I Komang Astina

State University of Malang

Doi:10.5901/mjss.2017.v8n1p397

\section{Abstract}

Punggawa-sawi is a member in fishing communities patorani, specifically fishermen hunt flying fish and flying fish egg collectors. The purpose of this research is: (1) describe the role of punggawa-sawi in religious rituals before going to sea, and (2) describe the role of punggawa-sawi in the process of catching the flying fish and eggs. This type of research is qualitative ethnographic approach. The research location in Takalar and the subject of research is punggawa and sawi greens in conserving flying fish resources. Data retrieval is conducted through observation, interview and documentation. The validity of the data carried out through the technique of triangulation, member check and audit trail. The results of the study suggesting that the role of punggawa-sawi greens flying fish in preserving resources, seen in two forms namely: (1) a role in religious rituals for safety and respect for the ruler of the sea. The ritual performed in the District Galesong coastal and island Sanrobengi. The ritual is, anynyikko pakkaja, appakruru bale-bale, apparek kalomping, annisik biseang, and songkobala. (2) The role of punggawa-sawi in the process of fly fishing visible in the form of arrest strategies using traditional fishing gear pakkaja and bale-bale. Measures to preserve the flying fish resources namely by letting the eggs are maturing gonat to rebreed being a flying fish.

Keywords: Punggawa-Sawi, Culture of Patorani, Flying Fish Resources

\section{Background}

Indonesia has 18 species of flying fish and 10 species of which located in the waters of South Sulawesi and the eastern region of Indonesia. Flying fish is a resource which is an idol for fishermen patorani. As the name implies that patorani is fishermen are specifically looking for fly fishing. Flying fish catches in Takalar South Sulawesi reaching 62075 tonnes in 2013. The catches increased in 2014 by $9.2 \%$, and in 2015 amounted to 11.2\% (BPS Takalar, 2016). Communities who depend on the sea such as fishing patorani has a lot of knowledge about the various symptoms of the sea and fishing 
techniques in order to make their production activity more effective.

Quantity catch flying fish the fisherman patorani did not change significantly. Fishing method originally done with a knowledge of behavior which is the maximum with a minimum capture tool. Turner (2014) mentioned that the knowledge society sustained by wealth and sharpness of observation which is not found in science outside society. Also due to their ability using a number of life experiences inherited from his ancestors rather than using modern knowledge.

Carrying capacity of the traditional fishing tool fishing patorani causing fishing activity whether the operation took place. Besides carrying fishing gear, there are couplets pangissengang (knowledge) to invoke the safety of the almighty creator. These forms of knowledge embodied in a series of ritual which must be done because it is believed to bring good luck. Punggawa-sawi becomes the main character in a series of fishing activities patorani. Punggawa is the skipper of the sea, and Sawi greens are the crew who played a major role in the process of fly fishing.

The role of punggawa-sawi greens flying fish in the preservation of resources projected in a manner consistent with the mindset and local traditions. It is expected is able to bring the concept and how to maintain the balance of environmental preservation. Various kinds of shape of restrictions, prohibitions, taboos, proverbs and various other traditions can reveal some of the messages which have enormous significance for the preservation of fish resources fly. The role of punggawa-sawi contained in a local culture patorani well-organized. Cultural values of the past (intangible heritage) is from the local culture in the archipelago, include: tradition, folklore and legends, the mother tongue, oral history, creativity (dance, song, drama performances), adaptability and uniqueness local communities (Galla, 2001).

This study, will explain the role of punggawa-sawi greens flying fish in preserving resources in the process of religious rituals and fishing techniques. Progressivity punggawa-sawi not shifting to the present. punggawa-sawi into a single inseparable in the course of fishing for fishermen patorani. To manage their activities with traditional fishing gear called pakkaja and bale-bale. The tool is very simple, but be a force for fishermen patorani in catching flying fish.

\section{Research Methods}

The type of research is qualitatve by using the etnographical approach. Etnographical approach is the study of the socio-cultural contexts, processes, and meanings within cultural systems. Each person's actions always contain something that is "unique" in line with the culture and traditions that exist in society it self. Implementation of this study followed the steps of qualitative research (Fatchan, 2013). Furthermore, the understanding taxonomically to find themes or domains. In gathering information, researchers examined the informant is to do with the question of non-structural measure to uncover the perpetrators of environmental sustainability. The location of this research in Galesong sub District Takalar Districk South Sulawesi Indonesia. The subject were member of patorani fisherman that specifically looking for flying fish and eggs. Subject selected in this research are punggawa (sea skipper) and sawi (the crew) in patorani fisherman community. Collecting data using observation, interview and documentation research. Checking the validity of the data using the technique of data triangulation, member check and audit trail. Analysis of data using interactive models as suggested by Miles and Hubermans (1997).

\section{Result}

Fishermen patorani is a unique community which is contained in Takalar South Sulawesi Indonesia. Patorani is a community with a complex organizational structure. Punggawa and Sawi are two very important role, in addition to indigenous stakeholders and society Galesong subdistrict. They have a characteristic catching flying fish and flying fish eggs only. Patorani number of fishermen in 2016 reached 2.168 fishermen (BPS Takalar, 2016). This number has increased from year to year because of the demands of the domestic market and abroad will be flying fish eggs. Flying fish catches in Takalar which reached 69.027 tonnes in 2015 an increase of 11.2\% (BPS Takalar, 2016). Results of flying fish eggs collected in 2015 which increased 5.7\% from 346 tonnes in 2010.

Fishermen patorani conduct their fishing activities with two important stages namely traditions /rituals performed before going to sea which was held in the District Galesong coast and local traditions in fishing techniques. Role punggawa and sawi will be explained through the following two matrices through a two-stage implementation of the patorani tradition. 


\section{Matrix 1. Punggawa-Sawi Role in Religious Ritual}

\begin{tabular}{|c|c|c|c|}
\hline No. & Informant & Information Provided & Domain Found \\
\hline 1 & \begin{tabular}{|l|} 
H. Bansuhari \\
Dg. Ngai \\
(punggawa) \\
The sea skipper
\end{tabular} & $\begin{array}{l}\text { - The right to prepare pakkaja given to the punggawa entrusted } \\
\text { power more than the other and has the soul of a leader. } \\
\text { - Pakkaja fishing gear prepared at } 07.00 \text { am and do at home } \\
\text { punggawa. } \\
\text { - Sawi and punggawa family required to follow a ritual anynyikko } \\
\text { pakkaja. } \\
\text { - Ritual significance is to prepare the hearts and intentions through } \\
\text { respect for pakkaja fishing gear in order to provide fruitful. }\end{array}$ & $\begin{array}{l}\text { Anynyikko pakkaja (Preparation gear } \\
\text { pakkaja) }\end{array}$ \\
\hline 2 & \begin{tabular}{|l|} 
Mansyur Dg. \\
Tata \\
(punggawa) \\
The sea skipper
\end{tabular} & $\begin{array}{l}\text { - Preparation of bale-bale conducted by anrongguru and punggawa } \\
\text { because ritual requirement will be a prayer. } \\
\text { - Sawi not required to participate in this ritual. } \\
\text { - The meaning of the ritual is to check the condition of the bale-bale } \\
\text { to use the check the size of the tool and the size of the hole which } \\
\text { will fly through the fish. The size of the holes are made must be in } \\
\text { accordance with the size of the adult flying fish, so that young age } \\
\text { they can be detached from the bench. }\end{array}$ & $\begin{array}{l}\text { Appakruru bale-bale (Preparation gear } \\
\text { bale-bale) }\end{array}$ \\
\hline 3 & $\begin{array}{l}\text { Rahim Dg. Jai } \\
\text { (sawi) }\end{array}$ & $\begin{array}{l}\text { - Kalomping is offering the package which must be taken by patorani } \\
\text { when fishing. } \\
\text { - Kalomping will be placed in the vessel and in every region through } \\
\text { which are considered sacred, with the intent to avoid the disruption } \\
\text { and danger at sea. } \\
\text { - Total kalomping made in one ritual patorani, approximately } 50 \\
\text { package. } \\
\text { - Kalomping shall also be placed on the island Sanrobengi as a } \\
\text { petition for permission before fishing. }\end{array}$ & $\begin{array}{l}\text { Apparek Kalomping (make kalomping, } \\
\text { namely offering packages which contain } \\
\text { traditional cake onde-onde, red rice, } \\
\text { cinnamon, and egg, wrapped in a betel } \\
\text { leaf) }\end{array}$ \\
\hline 4 & \begin{tabular}{|l|} 
Syamsul Dg. \\
Mattawang \\
(anrongguru) \\
atau guru adat. \\
The indigenous \\
teachers \\
\end{tabular} & $\begin{array}{l}\text { - Ship Patorani considered to have the spirit and soul. The vessel } \\
\text { must be cleaned and repaired through ritual annisik biseang. } \\
\text { - This ritual is performed by anrongguru, punggawa and sawi. } \\
\text { - Annisik biseang done in the morning before } 9 \text { am. }\end{array}$ & $\begin{array}{l}\text { Annisik biseang (Preparation of the ship } \\
\text { and the ship cleaning from bad influences) }\end{array}$ \\
\hline 5 & $\begin{array}{l}\text { Gunawan Dg. } \\
\text { Beta } \\
\text { (sawi) } \\
\text { The crew }\end{array}$ & $\begin{array}{l}\text { - Fishermen patorani must feel the excitement before going to sea } \\
\text { until they return from fishing. } \\
\text { - If they are happy and grateful hearts, it would also be making them } \\
\text { welcome with those describing the results of the flying fish and eggs } \\
\text { which is abundant like garbage piling up. } \\
\text { - Sanrobengi Island is an island that must be addressed before } \\
\text { patorani to sea, with the intent to apply for a permit make the } \\
\text { voyage. } \\
\text { - Fishermen patorani and their families, together do a party on the } \\
\text { island Sanrobengi. They brought food and drink that much as } \\
\text { gratitude for joy before they go to sea. }\end{array}$ & $\begin{array}{l}\text { Accaruk-caruk (Thanksgiving feast and } \\
\text { ritual refuse reinforcements /woe) }\end{array}$ \\
\hline
\end{tabular}

Matrix 1 shows that punggawa-sawi in fishing communities patorani plays a major role in the preparation phase before they go to sea. The preparation circuit performed in a religious ritual and sacred trust and must be done. If the ritual sequence there are not performing well, they believe will not get the results and even worth empty. They also will not go to sea if an error occurred in the execution of rituals, as they believe will meet the dangers on their way as a result of prayer and hope not conveyed properly to the spirit of the ruler of the sea. The second matrix will explain the role of punggawa-sawi when fishing process. 


\section{Matrix 2. Punggawa-Sawi Role in dalam Flying Fish Catching Process}

\begin{tabular}{|c|c|c|c|}
\hline No. & Informant & Information Provided & Domain Found \\
\hline 1 & $\begin{array}{l}\text { Mulawang Dg. } \\
\text { Sibali } \\
\text { (sawi) } \\
\text { The crew }\end{array}$ & $\begin{array}{l}\text { - Since the first time the foot set foot on the ship punggawa and sawi always accompanied } \\
\text { by prayer and ritual which will continue all the way to sea. } \\
\text { - They bring offerings which will be given to the ruler of the sea if they encounter difficulties } \\
\text { and dangers. } \\
\text { - Offerings named kalomping, which contains materials that are considered sacred and } \\
\text { wrapped in betel leaves. } \\
\text { - Kalomping is a mandatory provision in addition to supplies of food and fuel. } \\
\end{array}$ & $\begin{array}{l}\text { Respect the ruler of } \\
\text { the seas }\end{array}$ \\
\hline 2 & \begin{tabular}{|l|} 
Abdullah Dg. \\
Tuju \\
(punggawa) \\
The sea skipper
\end{tabular} & $\begin{array}{l}\text { - Punggawa saw the sign the existence of flying fish to find a location that the sea is } \\
\text { glittering from afar. } \\
\text { - Sawi read the signs of nature through the act of dipping his hands up to the elbow. If the } \\
\text { water is warm, it means there are lots of flying fish were spawning. } \\
\text { - Habits see signs of this nature including traditional, but bring satisfactory results. } \\
\text { - Habit of smell carried by the punggawa and sawi to recognize the existence of flying fish. }\end{array}$ & $\begin{array}{l}\text { The reading of the } \\
\text { signs of nature }\end{array}$ \\
\hline 3 & \begin{tabular}{|l|} 
Masrudding Dg. \\
Gassing \\
(sawi) \\
The crew
\end{tabular} & $\begin{array}{l}\text { - When arriving at the location which is estimated there are many flying fish, sawi then put } \\
\text { pakkaja and bale-bale as many as } 20 \text { pieces and left them ammanyu-manyu (floating). } \\
\text { - At each pakkaja put a piece of bamboo which measure about } 50 \mathrm{~cm} \text { which is bound } \\
\text { together gosse (a type of seaweed which smelled liked flying fish). } \\
\text { - Each pakkaja tied bale-bale in the middle of pakkaja, for flying fish as spawning grounds. } \\
\text { Bale-bale size is } 2 \times 1 \text { meter. On the outside pakkaja, tied coconut leaf midrib along with } \\
\text { a sign on each pakkaja in order to easily find them again. } \\
\text { - Coconut leaf sheaths have a slick and fibrous structure and was well liked flying fish to } \\
\text { spawn (lay eggs). }\end{array}$ & $\begin{array}{l}\text { Techniques in } \\
\text { putting pakkaja and } \\
\text { bale-bale }\end{array}$ \\
\hline 4 & \begin{tabular}{|l|} 
Syukur Dg. \\
Taba \\
(punggawa) \\
The sea skipper
\end{tabular} & $\begin{array}{l}\text { - Pakkaja and bale-bale appointed after drifting left floating for (at most) two days. } \\
\text { - If the punggawa-sawi no lift pakkaja and for } 2 \text { days, then the eggs collected in the bale- } \\
\text { bale will be released back into the ocean, because the egg has been cooked gonad. } \\
\text { - The eggs were mature gonads will be allowed to proliferate into fly fishing. } \\
\text { - Flying fish which netted pakkaja and bale-bale is the only adult-sized fish, flying fish are } \\
\text { young can come off easily. }\end{array}$ & $\begin{array}{l}\text { Techniques in } \\
\text { collecting flying fish } \\
\text { and flying fish eggs }\end{array}$ \\
\hline
\end{tabular}

Matrix 2 shows that patorani culture play a role in utilizing and conserving fish resources fly. The culture preserved to this day every time patorani fishing activity. Patorani culture supported by pangngissengang (knowledge) in reading the signs of nature and preserving the flying fish resources with the fishing techniques and traditional fishing gear.

\section{Discussion}

\subsection{Punggawa-Sawi Role in Religious Ritual}

Patorani is a ritual which is a reflection of confidence and passed on from generation to generation. At the beginning of each voyage to hunt flying fish and eggs, then the Patorani in this case the punggawa-sawi, carry out the ancestral traditions. Many patorani habits in preserving marine resources, not be part of in the management of coastal resources planned or carried out by the government. Habits (folkways) community in maintaining and managing coastal resources only a force which binds to the community itself (Kwadjosse, 2009). Community wisdom in its interaction with nature just become customary force in the form of habit it will be set at the level of their local communities alone.

Punggawa-sawi in patorani community, have confidence associated with spirits which are divided over the ancestral spirits, jinns and demons is called pakkammik (gatekeepers). Pakkammik was the guard, the lord and guard the goods and certain places that are considered sacred. A sacred place for fishermen patorani is in the oceans which they believe has pakkammik. Pakkammik believed to be a source of strength and also oversee the follow human behavior (Lampe, 2012). Pakkammik can bring in reinforcements disaster for those who commit a violation by the destruction of the natural order as well as custom order.

Implementation of religious rites before setting sail carried out jointly with other patorani fishermen. Rituals carried out two days before they go to sea. The first ritual performed in the District Galesong coast with the intention of respecting the fishing gear and sesajen (offerings) which will be taken as the provision of safety at sea. The second ritual performed on the island Sanrobengi with the intent to apply for a permit before going to sea and celebrate the excitement through the party with other patorani family. Customary law is still valid natural resource management, evidenced in the 
possession of individuals closely the place of residence (Painemilla, 2011).

\subsection{Punggawa-Sawi Role in dalam Flying Fish Catching Process}

Punggawa-sawi in fishing communities patorani has reference rules in livelihood activities. They are also requirements for knowledges in entering the sea region, where such knowledge contains the meaning and value that they must comply. If they break, then they will get the sanction of the head of customs and the sanction of nature. Compliance with the policy itself seen through the punggawa-sawi role in religious rituals before going to sea. Traditional sanctions collectively control the reaction against acts which violate customary law the respect for nature (Decaux, 2008). Rituals and rules as well as abstinence patorani always follow their journey over the sea.

In general there are two kinds of technology according to the source which has been developed by the fishing community patorani until today. The first is born to indigenous knowledge (local knowledge) with the use of information that is participatory, associative, analogik and orientatif which are often closely related to the old belief which is immanence and sourced from within. Second, engendered by science or by the use of scientific explanations which mostly comes from outside, into the community through contact with the outside world. Fishing techniques and gear is simple, be a force for fishermen patorani (Nasruddin, 2010). Pattorani fishing gear is the fishing gear made of woven bamboo cylindrical with a length of $100-125 \mathrm{~cm}$ with diameters ranging from $50-60 \mathrm{~cm}$.

Punggawa-sawi recognize a knowledge system called pangngissengang. The scope of this concept includes two main aspects namely the nature of knowledge and knowledge of spiritual birth. This pangngissengang system translated into erang passimbolongang (knowledge of the ins and outs of shipping) and erang pakboya-boyang (technological knowledge). Both of such knowledge as a reference for punggawa-sawi in the process of catching the flying fish and eggs. Knowledge of fishermen to the sea conditions, can help control the exploitation of fishery resources and conduct massive restrictions on access to fish resources, in order to guarantee the sustainability of resources in the future (Mathooko, 2005). Fly fishing activity influenced by the traditional knowledge of the sea and natural phenomena, including traditional astronomy and meteorology inherited from previous generations.

Knowledge of technology (erang pakboya-boyang) implemented through the use of fishing gear is simple namely pakkaja and bale-bale. Each stage in the implementation of activities at sea considered sacred because each activity requirement with pakdoangang (reciting). Bait chanted prayers when about lowering pakkaja and bale-bale can be seen in the following prayer temple (Nasrudin, 2010).

"Irate rammang makdonteng, ku pailalang sorongang. Naung ko mae, pirassiangnga tangngana biseangku. Rassi ipantarang, rassi ilalang. Oh Nabbi, sareanga dallekku ri Allah Taala, siagang Nabi Muhammad. Oh Nabbi Pakkere, Nabbi Hadere, sareanga mange dallekku ri Allah Taala siagang Nabi Muhammad".

Meaning: above the clouds agglomerate, full of hope. Come down, fill my boat. Full out, full inside. Oh Prophet (flying fish gods), provide sustenance from Allah SWT with the Prophet Muhammad. Oh Prophet Pakere, the Prophet Haidir, offer give my sustenance from Allah SWT and Prophet Muhammad ".

Every prayer and action punggawa-sawi over the sea, have meaning and purpose to get to safety and obtained abundant through pakkaja and bale-bale that has been their holy. Flying fish resources conservation shape looks at techniques allow the gonad maturity the flying fish eggs that are released into the ocean after 2 days the eggs were not taken. Punggawa and sawi wisely utilize fly fish resources and preserve their existence in the ocean for the benefit of fishermen patorani future. Punggawa-sawi is very sacred to carry out each stage required. If at some stage is not implemented, then the resulting general fear of the safety of shipping and the lack of sustenance will be obtained for the group (Keraf, 2002). The public perception of respect for customary fishing in the local culture is still very strong and adherence to traditional/customary law in the management of fish resources, quite large (Primyastanto, 2014). Many opportunities to empower local cultural values to be maintained and exploited in formulating the policy management of fisheries.

\section{Conclusion}

Sea not only as a physical environment, but also have the spirit and strength which gives a reaction which can hurt or harm if treated well. The views patorani, especially punggawa-sawi, emphasizing the form of respect for what he has given they live is the ocean and fly fishing. Role in preserving the punggawa-sawi flying fish resources is seen in two forms is punggawa-sawi role in religious rituals religious rites shaped for safety and respect for the ruler of the sea. The rituals performed in the coastal sub-district Galesong and on the island Sanrobengi. The ritual is anynyikko pakkaja, appakruru bale-bale, apparek kalomping, annisik biseang, and songkobala. Role of punggawa-sawi in the process of fly 
fishing visible in the form of arrest strategy using pakkaja and bale-bale. Measures to preserve the flying fish resources namely by letting the eggs are maturing gonat to breed back into fly fishing.

\section{References}

Baso, A. 2004. Management of Fisheries Resources Fish Fly (Cypsilurus spp) Sustainable In Makassar Strait and Flores Sea (A Study of Bio-Technical, Social Economy). Dissertation. Graduate Program. Hasanuddin University. Makassar.

BPS Kabupaten Takalar. 2016. Kabupaten Takalar in Figures Year 2016 BPS Kabupaten Takalar South Sulawesi Province. Makassar.

Dahuri, R. 2000. Utilization of Marine Resources for People's Welfare. Thought Collection. Institute of Information and Development Studies Indonesia. Jakarta.

Decaux, E. 2008. The definition of traditional sanctions: their scope and characteristics. Public Law at the University Panthe'on-Assas Paris II. International Review of The Red Cross. Volume 90 Number 870 June 2008. P.249-257.

Fatchan, Ach. 2013. Qualitative Research methods: Qualitative Research 10 Step Approach Construction and Etnography. Malang: UM Press.

Galla, A. 2001. Guidebook For The Participation of Young People In Heritage Conversation. Hall and Jones Advertising. Brisbane.

Keraf, A. Sony. 2002. Environmental Ethics. Kompas Book Publishers. Jakarta.

Kwadjosse, T. 2009. The Law of The Sea: Impacts on the Conservation and Management of Fisheries Resources of Developing Coastal States-the Ghana Case Study. The United Nations-Nippon Foundation of Japan. Fellowship Programme 2008-2009. Division For Ocean Affairs and The Law of The Sea Office of Legal Affairs, the united nations. New York.

Lampe, M. 2012. Marine Resources Management in the Coral Zone Takabonerate and Paradigm Environmental Communalism Bajo Past Society. Indonesian Journal of Social and Cultural Anthropology. Vol. 33 No. 3 September-December 2012. ISSN: 1693167X. p.216-224.

Mathooko, J.M. 2005. Application of traditional ecological knowledge in the management and sustainability of fisheries in East Africa: a long-neglected strategy? Department of Zoology, Egerton University, P.O. Box 536, Njoro. Kenya. Hydrobiologia (2005) 537: p.1-6.

Miles and Huberman. 1992. Qualitative Data Analysis. Jakarta. University of Indonesia (UI-Press).

Nasrudin, Lucas, Aurora, Faizal, Nur Alam. 2010. The Presence of the Expedition Trail Sailors Makassar in Australia's Northern Coastal XVII Century the Tradition of Maritime History Network Culture. Hasanuddin University. Makassar.

Painemilla, K.W., Rylands, A.B., Woofter, A., Hughes, C. 2011. Indigenous People and Conservation from Rights to Resource Management. Conservation International. ISBN 978-1-934151-39-6. Crystal Drive, Suite 500 Arlington, VA 22202. USA.

Primyastanto, M., Purwanti, P., Yahya. 2014. Fisheries Resource Management through Local institutions in Empowering Community Based on Local Wisdom in Coastal Madura Strait. International Review of Social Sciences. Vol. 2 Issue.5, May 2014. ISSN 23090081. P.136-147.

Turner, R. A., N. V. C. Polunin, and S. M. Stead. 2014. Social Networks and Fishers Behavior: Exploring the Links between Information Flow and Fishing Success in the Northumberland Lobster Fishery. Ecology and Society 19(2): 38. ES-06456-190238. 